\title{
Value-Based Delivery Of Education: MOOCs As Messengers
}

\author{
David M. Gilfoil, Ph.D., DeSales University, USA
}

Jeffrey W. Focht, Ed.D., DeSales University, USA

\begin{abstract}
Value-based delivery of healthcare has been discussed in the literature for almost a decade. The concept focuses on the patient and defines value as the improvement of patient outcomes divided by healthcare costs. Further refinements, called the Triple Aim model, focus on improving patient outcomes, reducing treatment costs, and improving patient satisfaction. Inspired by the MOOC (Massive Open Online Courses) movement in education, which should be seen as a wake-up message for educators, this paper attempts to reframe MOOCs, and related educational initiatives, within a Value-Based Delivery of Education (VBDE) model. The VBDE model focuses on the student learner and defines value as the improvement of learning outcomes, reduction of educational costs, and improvement of student stakeholder satisfaction. VBDE model elements are operationally defined, quantified, and used to identify and assess key components of MOOC and MOOC-related initiatives. Implications for the successful delivery of value-based education in the future are discussed as part one of a two-paper series on the topic.
\end{abstract}

Keywords: MOOCs; Massive Open Online Courses; Value; Value-Based Education; Learning Outcomes; Education Costs; Student Satisfaction; Technology; Pedagogy; Assessment

\section{INTRODUCTION}

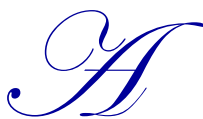

ccording to the Oxford English dictionary, value is defined as "the regard that something is held to deserve; the importance, worth, or usefulness of something" (Dictionary, 2002). In the business/marketing literature, value has taken on many forms - value proposition, customer perceived value, value creation, and customer value-add - just to name a handful. On a simplistic level, all these notions of business value have centered around the concept of a business or institutional entity providing products, services, or outcomes that, from the customer's perspective, result in some form of customer need fulfillment/benefit relative to the cost and effort of obtaining the product or service.

Value-based delivery of healthcare has been discussed in the literature for almost a decade. The concept focuses on the patient and defines value as the improvement of patient outcomes divided by healthcare costs. Further refinements of this value-based thinking, called the Triple Aim model, focus on improving patient outcomes, reducing treatment costs, and improving patient satisfaction. Domestic and global initiatives, based on value-based delivery of healthcare and the Triple Aim model, put forth by the Institute for Healthcare Improvement (IHI) are well underway and beginning to yield impressive results in key "pockets" of excellence. Many of these success stories are documented on IHI's website.

Given that higher education in the U.S. (and many countries) is suffering from some of the same value "ailments" as U.S. healthcare (lack of focus on the customer, high costs, poor outcomes), perhaps it can benefit from the same philosophical approach. Inspired by the recent MOOC movement in education, which should be seen as a wake-up message for educators, this paper attempts to reframe MOOCs (and related educational initiatives) within a Value-Based Delivery of Education (VBDE) model. The VBDE model focuses on the student learner and defines value as the improvement of learning outcomes, reduction of educational costs, and improvement of student stakeholder satisfaction. The VBDE model is also used to identify and assess key components of MOOC and MOOC-related initiatives. This paper is Part 1 of a two-part series introducing and exploring the VBDE concept. 
Part 1 attempts to operationally define VBDE model elements and provide examples of their quantification. Implications for the successful delivery of value-based education in the future are likewise discussed within the context of the model in part 1 . Part 2 , a follow on paper, will attempt to more fully validate the model by providing a more exhaustive review of the empirical literature relating to the VBDE model.

\section{LITERATURE REVIEW}

\section{Business Definition of Value}

Value, from a business marketing perspective, is typically thought of as the degree to which a good/service is perceived by the customer to meet their needs or wants as influenced by the customer's willingness to pay for it (Kotler, 2012). Value has also been defined in the research literature as a tradeoff between benefits and sacrifices (Flint, et al., 1977; Ravald \& Grönroos, 1996). Expanded value conversation in business/marketing venues have taken on many forms; the concepts "value proposition", "customer perceived value", and "customer value add" are most notable and are further defined below.

Value proposition, as defined by Lanning \& Michaels (1988) and Lanning \& Phillips (1991) is both a statement of benefits offered to a customer group and the price a customer is willing to pay for those benefits. The value proposition simply articulates the relationship among the performance of the product or service, the fulfillment of the customer's needs, and the total cost to the customer over the customer relationship life cycle. Development of a value proposition involves three key steps: (1) creating/defining the value of a product or service, (2) providing the value, and (3) communicating the value. Marketing and sales professionals often are trained to sell value propositions when addressing important customers. Anderson, et al. (2006) provide a compelling review of value proposition fundamentals in the Harvard Business Review.

Customer perceived value has its roots in equity theory, which considers the ratio of the customer's outcome/input to that of the service provider's outcome/input (Oliver \& DeSarbo, 1988). The equity concept refers to the customer evaluation of what is fair or equitable for the total perceived cost of the product or service (Bolton \& Lemon, 1999). Perceived costs include monetary payments and nonmonetary sacrifices such as time consumption, energy consumption, and stress experienced by consumers. Oliver \& DeSarbo (1988) suggest that customerperceived value results from an evaluation of the relative rewards and sacrifices associated with the offering. They further contend that customers often measure a company's ratio of outcome to inputs by making comparisons with its competitors' offerings. McDougall and Levesque (2000) developed a comprehensive model of customer satisfaction in service settings that incorporates customer perceived value. Their research showed that customer perceived value and perceived service quality led to high customer satisfaction which led to a greater likelihood that customers would purchase again in the future.

Finally, the concept of Customer Value Add (CVA) was introduced by Gale \& Wood (1994) to further advance an important notion about value and customer satisfaction. Gale and Wood's fundamental idea was that businesses add value as perceived by their customers (or not) in the production of their goods or services. They contended that certain CVA attributes (i.e. technology, quality, responsiveness, total cost, communication) are important to specific company or institutional customers. If these companies/institutions are to be successful, they must figure out what those CVA attributes are, and which ones are more important than others to their target customers. Furthermore, they should reach out to their customers to also ask how the company is performing against each of the weighted CVA attributes, and how they are performing on these attributes relative to their key competitors! Others have further expounded on the CVA concept and/or have reviewed how impactful the CVA methodology has been in a variety of business settings (Laitamaki and Kordupleski, 1997; Higgins, 1998; Kordupleski, 2003; Lindgreen and Wyndstra, 2005; Olaru, Purchase, and Peterson, 2007).

\section{Value in Healthcare}

The concept of value has also crept its way into the healthcare literature. Healthcare in America has been in trouble for some while. It has cost problems, it has problems with respect to poor measureable outcomes (i.e. infections, morbidity, mortality), and it has problems with unhappy or disgruntled patients. The Institute of 
Medicine (IOM), an independent, non-profit organization, has indicated that healthcare costs have exceeded $18 \%$ of U.S. Gross Domestic Product (GDP). In addition, the IOM reports that there is approximately $\$ 765$ billion in wasted annual spending in American healthcare (IOM, 2012). From an outcomes perspective, at the turn of the millennium approximately 100,000 Americans died annually due to healthcare mistakes (Kohn, Corrigan \& Donaldson, 2000). According to data from the Office of the Surgeon General, that number has now risen to between 200,000 and 450,000 people each year (James, 2013). Healthcare leaders from industry and academia are acutely aware of these issues and, in the last decade, have begun to make headway in addressing them. Harvard professor Michael Porter teamed with Elizabeth Teisburg from Sweden to write a seminal book entitled "Redefining Health Care: Creating Value-Based Competition on Results" (Porter \& Teisburg, 2006) in which they articulated the need to measure healthcare value as patient health outcomes per dollar spent. Porter and others further expounded on the need for fundamental restructuring of healthcare delivery (Porter, 2009, 2010, Kaplan \& Porter, 2011). While much work still needs to be done, the work started by Porter and Teisburg has now evolved into a simple value-based model espoused by the Institute for Healthcare Initiatives (IHI) as the Triple Aim model (IHI, 2009). Triple Aim (see Figure 1) has been adopted across a broad spectrum of U.S. healthcare organizations and credited for launching tens of thousands of quality initiatives since its debut in 2009.

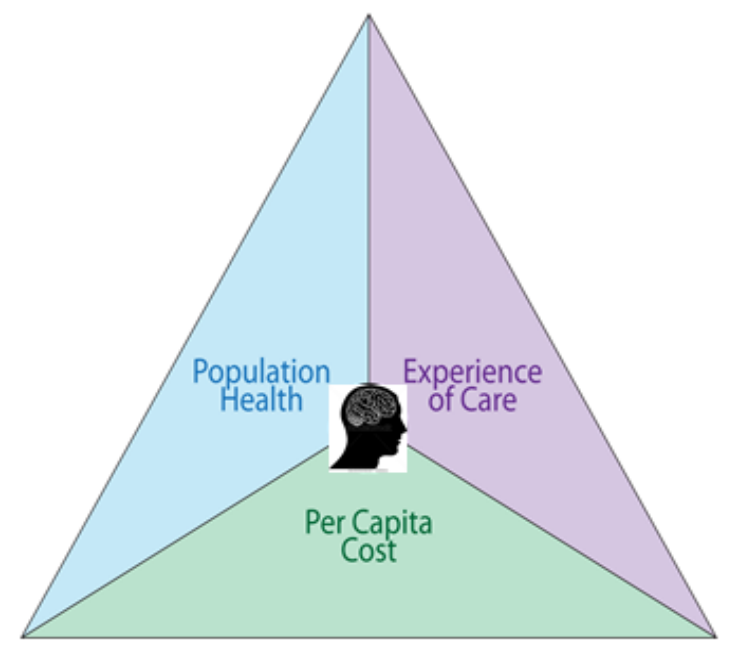

Figure 1. IHI Triple Aim Model for Value-Based Delivery of Healthcare

As can be seen, the value-based model places the patient at the center of care, and focuses on improving population health (outcomes such as reduced infections or mortality rates), reducing per capita cost (including hospital and Emergency Department utilization rates), and improving the patient's experience of care (i.e. Hospital Consumer Assessment of Health Care Providers and Systems (HCAHPS) survey; "likelihood to recommend" metric).

The Institute for Healthcare Initiatives (IHI) website contains references to select Triple Aim success stories (IHI, 2014) involving quality initiative program launches - resulting in improved outcomes, reduced costs and/or improved patient satisfaction. Additional Triple Aim success stories abound. A recent book by Bisognano \& Kenney (2012) shares innovative approaches, effective deployment, and compelling results from approximately twenty innovative health care cases such as Virginia Mason Medical Center, Kaiser Permanente, ThedaCare, Cincinnati Childrens Hospital, and Intermountain Healthcare. Triple Aim successes are also documented by Ory, et al. (2013), Jortberg \& Fleming (2014), and Gottlieb (2013) who provides a detailed case study of a healthcare value improvement initiative of the Nuka Indian population in Anchorage, Alaska. 


\section{Value in Higher Education}

Similar to healthcare in America, the educational system, overall, has received much criticism for its lack of value - namely its high costs, poor outcomes and lack of overall satisfaction (Zemsky, 2013). Higher education in America, while often recognized as being more globally competitive (Altbach, 2014), is being challenged (as in other parts of the world) by the recent onslaught of business-savvy entrepreneurs and bottom-line oriented individuals bringing new ideas and different templates for measuring success (and value). The entry of "for-profit" (mostly online) programs like Phoenix, Strayer, Kaplan, Capella, American Public University System and the like, caused a stir at first because of their simpler, lower-cost business model, use of online formatting, and steep growth curves. As a group, however, the "for-profits" recently met with some disdain (and trouble with the government) over lax admissions policies, excessive government loans to students, and meager graduation rates - suffering significant market declines in the 2010-2013 timeframe (Fain, 2011; Krupnick, 2013). Nevertheless, these market entrants have played a key role in American education by shaking things up and delivering education differently online, efficiently, and with an emphasis on innovation. Indeed, the entrepreneurial onslaught of for-profit universities and subsequent metamorphosis in the structure and delivery of higher education, cannot be denied. Traditional university models, on the other hand, have been slow and lackadaisical in reaction to the ever-changing landscape of student need, accountability measures, transparency expectations, and public scrutiny. Zemsky (2013) articulates this distress:

For decades now, higher education's truth tellers and prognosticators, including me, have been predicting that American higher education is about to change because it has to change. Every Monday morning or so, it seems, we lay out all the pressures - rising costs, unequal access, confusing curricula - that, like the signs of an impending earthquake and accompanying tsunami, are but announcements that all the wrongs of American higher education are about to be swept away (p. 3).

Some would argue that this "... impending earthquake and accompanying tsunami ..." is not impending at all, but is already underway.

A second "wave" of traditionally brick and mortar type educational institutions (i.e. Liberty University and Southern New Hampshire University) grabbed higher education's attention in the last five years or so. Some of them hired entrepreneurial business leaders who saw the benefits of leveraging technology and online pedagogical models, driving down the overall cost per student - all while preserving their traditional campus environment (Kamenetz, 2012). They have captured the attention of the educational marketplace and used much of their profits on aggressive marketing to grow even further (Lee, 2014). Similar to some of the "for-profit" players, they have successfully adapted a different model, introducing a value proposition based on technology, online formats, and lower cost per tuition credit hour. Some of these institutions are also capitalizing on the competency-based education movement. This newest paradigm allows students to progress through individualized academic programs once proficiency is demonstrated in various content areas. These online enrollees progress at their own pace, and if diligent in their studies, have a higher propensity to earn degrees, or other credentials, in a much shorter time span compared to traditional educational time structures (U.S. Department of Education, 2014). Taken together, these progressive institutions discussed above have made academia think about what needs to be done to improve the value equation - and how to survive the next phase of higher education in America.

Defining value in higher education can be challenging due to multifaceted viewpoints on the subject (Carlson, 2013). For example, Borwick (2013) breaks down higher education "value" into three distinct areas immediate value (i.e. social benefits, physical location/facilities, community impact, etc.), short-term value (i.e. enhanced knowledge and abilities, soft-skills, critical thinking, career assistance), and long-term value (i.e. employment, increased salary with a degree, alumni network, personal and social recognition). Borwick suggests that these three areas will vary depending on what institution one attends and hence, the level of student-derived satisfaction.

Ojalvao (2013) reveals five traditional value propositions in higher education. The first value element involves learning in a demanding, supportive environment where educational resources are abundant. The second value is the ability for social interaction and cultivation of friendships. Third, is a higher social status depending on 
the college or university one attends or from where they earn a degree. The fourth value of higher education is selfdiscovery or the ability for one to hone his/her interests over time. The fifth and final value proposition is marketability and earning potential compared to those without degrees. This value is easier to quantitatively assess in surveys compared to areas such as social interaction and cultivation of friendships.

Regarding earning potential, Rampel (2011) reveals that median salaries for college graduates are actually decreasing while college debt (due to escalating costs) is increasing - a factor requiring urgent attention within the higher education value equation. Reducing costs in higher education calls for a need to decrease costs directly and indirectly in both the institutional delivery of education and a reduction in costs/debt for the student. Most recently, the value of higher education has even been discussed in terms of ROI - Return-on-Investment. Carlson (2013) in The Chronicle of Higher Education notes:

Looking at college explicitly in terms of its "return on investment," measured in starting salaries and potential earnings, is something new-a confluence of anxieties about the rising cost of college, mounting debt among students, a flaccid economy, and the ubiquitous vocabulary of the market. This perspective is everywhere now, embedded in the U.S. Department of Education's College Scorecard, the college "ROI rankings" from the salary-tracking company PayScale, the countless recent books assessing the value of college, and The Chronicle's own new tool, College Reality Check (p.3).

Given so many approaches to defining the value of higher education, a new Value-Based Delivery of Education (VBDE) model is presented (below) within the context of the Triple Aim Model in healthcare of improved outcomes, reduced costs, and increased student stakeholder satisfaction. This VBDE model is presented through the lens of MOOCs.

\section{Massive Open Online Courses (MOOCs)}

Adding to this dynamic evolution is the most recent wave of change in U.S. higher education - the appearance of Massive Open Online Courses (MOOCs). MOOCs have been largely driven by IT-centric business entrepreneurs (i.e. Udacity, Coursera, and EdX), who created a business partnership model with elite institutions (i.e. Stanford, MIT, Harvard, Wharton) in a concerted effort to change the value equation. MOOCs are educational classes that are:

- designed to accommodate thousands of simultaneous students in the (global) marketplace (massive).

- $\quad$ intended to be readily accessible to the general public at no, or minimal, cost (open).

- $\quad$ available via the internet (online).

While MOOCs formally made their way to U.S. higher education prior to 2012 (Siemens, 2010; Kop, 2011; Masters, 2011), much of the published literature declaring MOOCs to be "a disruptive force" began to appear in 2012 (Lawton and Katsomitros, 2012; Skiba, 2012; Vardi, 2012) - which was dubbed "the year of the MOOC" by the New York Times (Pappano, 2012). Since that timeframe, there has been some debate about whether MOOCs really pose a threat to higher education. Some have argued that MOOCs should not be taken so seriously because:

- $\quad$ completion rates are extremely low (Fisher, 2014; North, Richardson, \& North, 2014).

- $\quad$ MOOC business owners have not yet developed a sustainable business model (Dellarocas \& Van Alstyne, 2013; Lucas, 2014).

- $\quad$ MOOC deliverables have not been productized where certificates or degrees have been conferred in any meaningful way (Sandeen, 2013; Finkel \& Masters, 2014).

Others, however, are arguing that MOOCs should not be counted out, and should still be taken seriously; those authors have pointed out that:

- worldwide adoption of MOOCs is on the rise (Vihavainen, Luukkainen, \& Kurhila, 2012; Asfar, 2013). 
- $\quad$ data are beginning to emerge showing that MOOCs yield favorable results (Lucas, 2014).

- $\quad$ some higher education institutions have indeed, begun to productize MOOCs (Cusumano, 2013; Lucas, 2014).

Whether one believes that MOOCs are a passing fad, or are at the forefront of an academic revolution, the authors believe that MOOCs (along with the "for-profits" and institutions with very large online components) are serving a meaningful purpose. They are calling into question the value proposition of higher education in America and offering alternatives that perhaps can improve that value proposition. While many management gurus in the 1990's, including Michael Porter (Porter, 1991), were laying the groundwork for understanding and delivering value in business, the battle cry for increasing value in American higher education has only recently gotten attention (aside from the MOOC movement being discussed here). Specifically, a number of recent articles and studies have documented the fact that overall progress made in improving the value of higher education remains paltry (Cusumano, 2014; Lucas, 2014). The most compelling indictment about U.S. higher education comes from Andreas Schleicher, an educational expert from the Organization for Economic Cooperation and Development (OECD), a well-known global non-government organization. Schleicher states " Institutions of higher education in the United States extract a lot of money without delivering value..." (Porter, E. 2014). Other similar, individual criticisms ultimately call out the need for enhanced value through improved outcomes, lower cost, and improved student satisfaction in the higher education system (Zemsky, 2013).

\section{PROPOSED MODEL: VALUE-BASED DELIVERY OF EDUCATION (VBDE)}

As can be seen from the model presented in Figure 2, the current authors suggest that value in the delivery of higher education in the U.S. (and elsewhere) can be enhanced by focusing on educational system outcomes, researching which technological, pedagogical, and assessment factors drive those outcomes, and then taking actions to achieve them. Improved outcomes, for example, can be measured directly in the short term (i.e. higher test scores), and indirectly in the long term (i.e. higher graduation rates). Next, identifying the drivers of critical and unnecessary cost elements - and reducing or eliminating the unnecessary ones - is paramount given the hue and cry about institutional operating costs, escalating tuitions, and staggering college debt. Both direct and indirect measures of cost reduction can be tracked. Lastly, but perhaps more difficult to get a handle on, is that higher education institutions must not only identify key, prioritized determinants of student satisfaction, they must figure out how to deliver those experiences in a more than satisfactory way (measured directly/indirectly) - if they are to prevail.

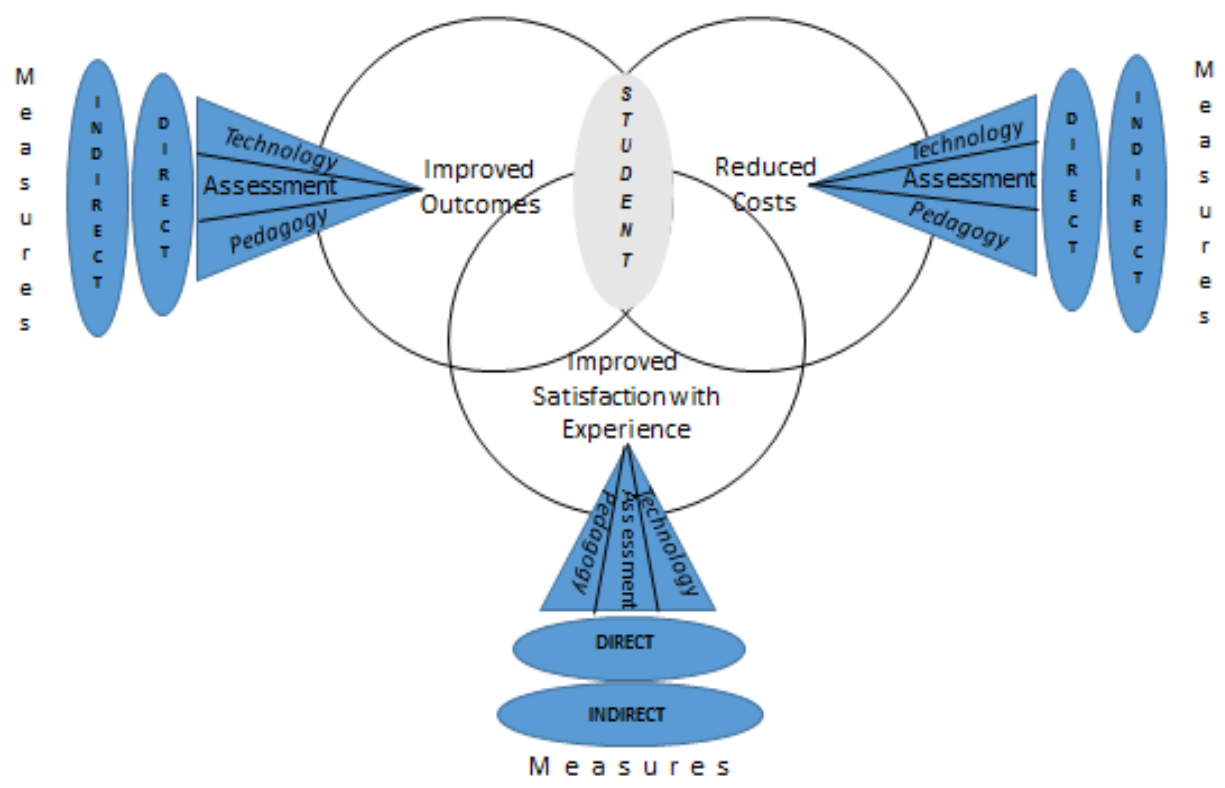

Figure 2: Proposed Value-Based Delivery of Education Model - Improving Outcomes, Costs, Satisfaction 
Taken separately, each of the three value components (outcomes, cost, satisfaction) of the VBDE model can be broken down into meaningful sub-elements that can be operationalized, measured and improved - once we understand the drivers of each.

\section{DISCUSSION}

\section{Improving Educational Value - What MOOCs Can Teach Us}

Some of the commonly cited MOOC characteristics that play a role in enhancing the value proposition of U.S. higher education are discussed below. Table 1 (from the authors' VDBE model) classifies multiple MOOC characteristics as Technological, Pedagogical, or Assessment related. The potential value proposition of each key MOOC characteristic is designated as Moderate-High $(\checkmark+$ ), Low-Moderate $(\checkmark)$, or Little-No impact (blank box) in these three areas. These three major categories reveal some trends that create a compelling synergy that suggest the beginnings of an improved value proposition for higher education.

The rise of online learning and subsequent expansion of MOOCs and related initiatives over the last decade have resulted in an increased blending of emerging technologies with traditionally-proven learning theories. According to Allen \& Seaman (2015), this integration has begun to improve optimal knowledge acquisition and retention and is crucial for continued enhancement of overall educational value. Furthermore, this blending of instructional technologies and pedagogical practices (first two categories in Table 1) is not specific to online courses only. It extends into hybrid and on-site classes as well - given that most face-to-face teaching is rapidly moving away from a style once dominated by mere lecture (Marcinek, 2014). Magana \& Marzano (2014) attribute this movement to societal/demographic changes, Generation $\mathrm{Y}$ and $\mathrm{Z}$ cohorts who expect increased use of technology, and the increasing intrusion of technology into everyday life (i.e. social media, mobile phone apps, and video games). The authors of the present paper observe that MOOC designers have considered such trends, and as a result, some of their contributions are helping to drive a new Value-Based Delivery of Education (VBDE) model. Assessment of student learning (the third category in Table 1) is also a key driver of the VBDE value equation. Zemsky, Wegner, and Massey (2006) state in Remaking the American University: Market-Smart and MissionCentered that, after the quality movement became widespread across business and other industries in the 1990s, government and accrediting bodies began questioning “. . . why educational institutions weren't following suit" (p.143). Today, each of the six regional U.S. accrediting organizations (i.e. Middle States, North Central, etc.) assess the effectiveness of student learning as part of the value impact and accountability of educational institutions (Middaugh, 2010). Such measurement takes place a number of ways through summative and formative assessment in online courses and MOOCs to enhance learning outcomes (Gikandi, Morrow, and Davis, 2011). 
Table 1. Key MOOC Characteristics and Potential Value Impact Measures

\begin{tabular}{|c|c|c|c|c|}
\hline $\begin{array}{c}\text { MOOC } \\
\text { Characteristic }\end{array}$ & $\begin{array}{l}\text { Improve } \\
\text { Outcomes }\end{array}$ & $\begin{array}{l}\text { Reduce } \\
\text { Student } \\
\text { Cost }\end{array}$ & $\begin{array}{c}\text { Improve } \\
\text { Student } \\
\text { Satisfaction }\end{array}$ & $\begin{array}{c}\text { Direct } \\
\text { Measure(s) }\end{array}$ \\
\hline & \multicolumn{3}{|c|}{ Potential Value Impact } & \\
\hline \multicolumn{5}{|l|}{ Technological } \\
\hline $\begin{array}{l}\text { Massive Online Platform }-3^{\text {rd }} \\
\text { Party (i.e. Coursera) }\end{array}$ & & $V_{+}$ & & $\begin{array}{ll}\text { - } & \text { Development costs } \\
\text { - } & \text { \# students engaged } \\
\text { - } & \text { Satisfaction scores } \\
\end{array}$ \\
\hline Short Video Clips & $V_{+}$ & & $\sqrt{+}$ & $\begin{array}{ll} & \text { Knowledge retention } \\
- & \text { \# Video replays } \\
\text { - } & \text { Satisfaction scores } \\
\end{array}$ \\
\hline Discussion Forum & & & $\checkmark$ & $\begin{array}{ll}\text { - } & \text { \# Peer interactions } \\
\text { - } & \text { Satisfaction scores } \\
\end{array}$ \\
\hline $\begin{array}{l}\text { Instant Feedback Quizzes } \\
\text { (computer-driven) }\end{array}$ & $V_{+}$ & & & $\begin{array}{ll}\text { - } & \text { Knowledge retention } \\
\text { - } & \text { Faster learning curves } \\
\text { - } & \text { Fewer facilitators } \\
\text { - } & \text { Satisfaction scores }\end{array}$ \\
\hline $\begin{array}{l}\text { Gamification } \\
\text { (motivation to learn) }\end{array}$ & $\checkmark$ & & & $\begin{array}{ll}\text { - } & \text { Student engagement } \\
\text { - } & \text { Satisfaction scores }\end{array}$ \\
\hline \multicolumn{5}{|l|}{ Pedagogical } \\
\hline "Flipping" the Class & $\checkmark$ & & & $\begin{array}{ll}\text { - } & \text { Faster learning curves } \\
\text { - } & \text { Knowledge retention } \\
\text { - } & \# \text { student inquiries } \\
\text { - } & \text { Satisfaction scores } \\
\end{array}$ \\
\hline Active Learning & $\checkmark$ & & & - $\quad$ Knowledge retention \\
\hline Self-paced learning & $V_{+}$ & & $\sqrt{+}$ & $\begin{array}{ll}\text { - } & \text { Fewer dropouts } \\
\text { - } & \text { Satisfaction scores } \\
\end{array}$ \\
\hline $\begin{array}{l}\text { Peer Instruction/Learning } \\
\text { (learning by teaching) }\end{array}$ & $\checkmark$ & $\checkmark$ & $t$ & $\begin{array}{ll}\text { - } & \text { Knowledge retention } \\
\text { - } & \text { Student engagement } \\
\text { - } & \text { Fewer facilitators } \\
\text { - } & \text { Satisfaction scores } \\
\end{array}$ \\
\hline \multicolumn{5}{|l|}{ Assessment } \\
\hline Auto graded "Inline" Testing & & $\sqrt{+}$ & $\sqrt{ }$ & $\begin{array}{ll}\text { - } & \text { Fewer facilitators } \\
\text { - } & \text { Faster learning curves } \\
\text { - } & \text { Assessment data } \\
\text { - } & \text { Satisfaction scores } \\
\end{array}$ \\
\hline Peer-graded Assignments & & $V_{+}$ & $\sqrt{ }$ & $\begin{array}{ll}\text { - } & \text { Fewer facilitators } \\
\text { - } & \text { Student engagement } \\
\text { - } & \text { Satisfaction scores } \\
\end{array}$ \\
\hline Course Assessment & $V_{+}$ & $\sqrt{+}$ & $\sqrt{ }$ & $\begin{array}{ll}\text { - } & \text { Assessment data } \\
\text { - } & \text { Faster course re-design } \\
\text { - } & \text { Satisfaction scores } \\
\end{array}$ \\
\hline
\end{tabular}

While an in-depth literature review of support data is underway (Part 2 - an upcoming publication), several research-based examples of key MOOC characteristics, and their impact on value measures, are provided in the Technological, Pedagogical, and Assessment categories below (from Table 1):

\section{Technological Characteristics - Definition and Examples}

Technological characteristics include unique aspects of how the courses are created, edited, and delivered online. For example, it is suggested that Short Video Clips likely have a Moderate-High positive impact in the improvement of both student learning outcomes and student satisfaction. Infusion of these short videos is pedagogically proven to increase retention and more importantly, reinforce learning objectives and proficiency (Williams, 2013). Similarly, showing these short clips expands the range of diverse learning styles (such as visual 
and auditory learning) making the course more robust and increasing the likelihood of higher student satisfaction with the course (Williams \& Williams, 2014).

Williams (2013) presents scientific data on the effectiveness of short video clips in MOOCs, drawing from a statistics course offered by Udacity, as well as math courses from Khan Academy. MOOCs with imbedded videos typically are accompanied by prompting questions that require the student to answer questions on a topic, before, during, and after a video clip, as opposed to just receiving the answers from an instructor in the video. Research proves that augmenting short video clips with prompting questions before, during, and after not only allows a student to be more engaged in subject content, it increases learning compared to straight "lecture" of material. Short video clips, in this regard, contribute to what Williams (2013) refers to (in online instruction) as the "malleability of intelligence" - where both motivation and cognitive processing are enhanced. This malleability increases the number of problems a student attempts, increases retention, and shortens the timeline to obtain mathematical proficiency. Increasing retention and efficiency is a direct measure of the VBDE Model (Figure 3) related to Knowledge Retention Scores and Time to Master Materials, and an indirect measure in that it strengthens an overall Student Retention Rate due to improved student satisfaction. A more comprehensive review of the educational literature on effectiveness of short video clips (Kay, 2012) cited benefits including positive attitudes toward video podcasts, control over learning, improved study habits, and increased learning performance.

\section{Pedagogical Characteristics - Definition and Examples}

Pedagogical characteristics include unique aspects of learning materials, structure and order of presentation, student-faculty interaction, peer instruction, automated feedback, and so on. Peer-to-peer instruction, or peer learning, is often a major element of a well-designed MOOC. Since the number of students in a MOOC is typically very high, instructor interaction is either limited, delegated to a teaching assistant, or nonexistent (Khalil \& Ebner, 2013). One way to counteract this limited instructor/student interaction is through peer instruction and automated personalized feedback (Sampson \& Karagiannidis, 2002). Materials and subject-related questions are posed to students on discussion boards to foster collaboration, debate, and engagement. The results are reduced costs (fixed instructor compensation) and improved student satisfaction (Lucas, 2014; Kolowich, 2012). Studies also indicate that peer instruction/learning (learning by teaching) is highly effective. Gikandi, Morrow, and Davis (2011), for example, report that peer-to-peer learning enables students to reflect and compose thoughts regarding course content. Lapp, Wolsey, and Ganz (2008) further elaborate that peer feedback and teacher to student feedback increases both motivation and satisfaction. Increasing student engagement is a direct measure of the VBDE Model (Figure 3) and an indirect measure in that increased satisfaction and performance decrease the likelihood of course repeats.

Assessment Characteristics - Definition and Examples

Assessment characteristics include unique aspects of MOOCs related to course evaluation, grading, certification, or other validating mechanisms of the learning process. For example, when a student completes a quiz in a MOOC, immediate results are produced for the student and also extrapolated into a database incorporating results from all participants in the course. Instructors, course designers, and administrators can analyze these results and assess levels of proficiency in various categories. If the vast majority of students answer a question incorrectly, this immediate feedback allows the assessor to revisit and modify or enhance curriculum or instructional materials and methods swiftly, thus increasing future student knowledge retention for that aspect of the course. According to Anderson (2011), this automated assessment structure significantly improves outcomes and student satisfaction while reducing student cost.

Banta, Jones, and Black (2010) have identified an increasing trend on the part of faculty and administrative personnel to embed, track, and measure multiple assessments within the student learning process. In fact, many companies external to colleges and universities (i.e. Taskstream) actually offer assessment tracking databases to analyze student performance throughout various courses from freshman year to graduation. This service is offered in an effort to build electronic portfolios that actually validate the progression of learning and skill acquisition for individual students. Such portfolios also allow for students to reflect on their learning and have a visual map of their skill and knowledge progression over time. From an institutional perspective, such systems constantly assess 
student performance (as in MOOCs). This allows for the collection and evaluation of direct evidence of student learning in real-time - evidence relating to what course, program, and institutional-level changes are needed to improve quality of outcomes, reduce costs, and increase student satisfaction.

One example of an online assessment technique is Auto Graded "Inline" testing which provides immediate feedback to the student as well as extrapolation of data regarding student performance. Assessment data of this sort increases the value proposition in higher education by strengthening course analytics, which are a direct measure of the VBDE Model (Figure 3) and an indirect measure, in that satisfied students will have a higher propensity to report satisfaction on graduate surveys. Substantial success has been reported on automated grading and feedback systems in several restricted domains, including essay evaluation using natural language processing (NLP) (Southavilay et al., 2013), computer program evaluation (Gulwani et al., 2014; Rivers et al., 2014), mathematical proof verification (Cramer et al., 2010), and recently, open responses to mathematical questions (Lan et al., 2015) .

\section{Linking Key MOOC Elements to Direct and Indirect Value Metrics}

From Table 1 we can begin to see that there are key technological, pedagogical, and assessment related aspects of MOOCs that are potentially making a difference in impacting the value of higher education. Taking the next logical step, the authors posit, via Figure 3, a framework to:

1) develop and refine a taxonomy of MOOC characteristics that may be impacting the higher education value equation. An initial suggestion of Technology, Pedagogy, and Assessment is put forth in this paper.

2) develop and refine research regimens that articulate which MOOC characteristics within each category are driving improved outcomes, which are driving down costs, and which are moving the student satisfaction needle in the right direction.

3) consider empirical data from MOOC classes (past and current) that attempt to validate which characteristics, elements, or methods result in improvements in short-term, direct measures such as higher test scores, higher course evaluations, and student engagement levels.

4) consider how key MOOC attributes are also contributing to the broader, longer-term, value proposition as measured indirectly by such variables as higher graduation rates, improved job placement, and lower loan default rates.

Some initial examples of these impactful MOOC attributes have been embedded in the Definition and Examples sections above. A much more robust set of research findings and online course design guidelines is currently underway. 


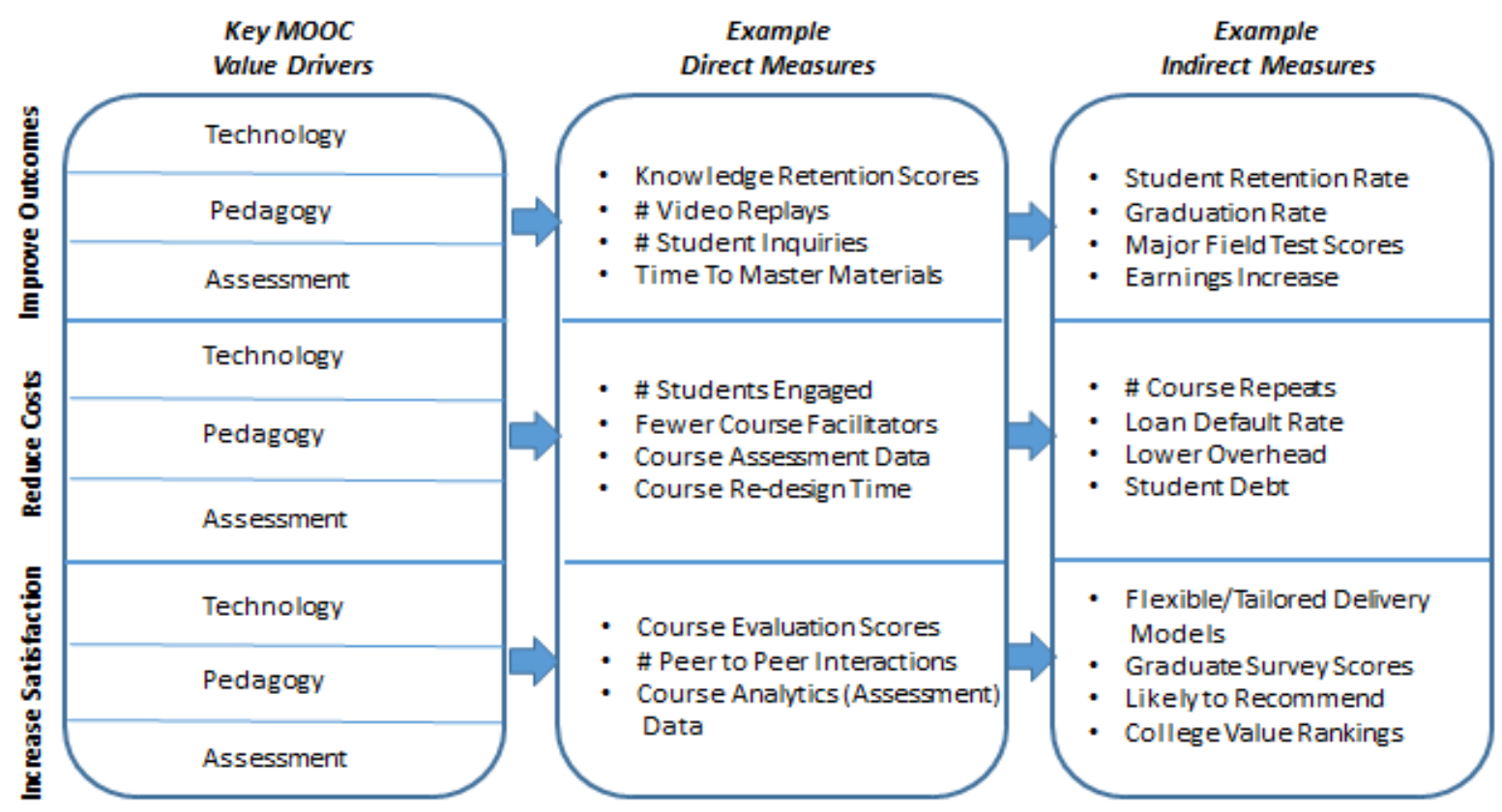

Figure 3. Understanding Drivers of Direct and Indirect Value Measures in Higher Education

\section{SUMMARY \& CONCLUSION}

Education, like healthcare, is going through a crisis in America. The primary issue, in both sectors, appears to be around the concept of a diminished or limited value proposition as perceived by the "customer" stakeholder in each system. The Value-Based Delivery of Healthcare model has recently proven to be an effective catalyst to improve outcomes, reduce treatment costs, and improve satisfaction from the patient's perspective. This so-called Triple Aim healthcare model can readily be adapted as a framework for the development of a Value-Based Delivery of Education (VBDE) model. The student learner is the focal point of the VBDE model and defines value as the improvement of student learning outcomes, reduction of educational costs, and improvement of student stakeholder satisfaction with the educational experience.

In the current paper, the VBDE model is proffered as a viable backdrop to begin to evaluate key characteristics of Massive Open Online Courses (MOOCs) in an attempt to better understand what role they might play in enhancing the perceived value of higher education. The authors argue here that whether or not MOOCs will revolutionize higher education or whether they are just a flash in the pan - is not really important. What is important is that they be seen as another "wake up" call for higher education to consider the value equation - from the student's perspective.

Although much has been published about MOOCs (both pro and con), there appears to be a very limited repository of published empirical data that clearly shows which MOOC characteristics work, which do not, and why. The authors have attempted to identify and discuss a preliminary taxonomy of technological, pedagogical, and assessment characteristics of MOOCs that could plausibly enhance higher education's value proposition. A framework is also proposed for articulating and evaluating successful MOOC design characteristics as measured directly by short-term measures (test scores, course evaluations) and longer-term, indirect measures that address a broader set of educational values (graduation rates, job placement, student debt). Some preliminary research data is discussed herein, but a larger, more comprehensive effort is required.

While education in America is clearly evolving, one certainty is that the current trajectory and speed of evolution is unacceptable and unsustainable for many educational providers - who may not survive if they do not heed the warning from the MOOC messengers. There are too many institutions, not enough students who can afford what they are offering, and many who are going through the process but are not happy with either the outcome or 
the experience. Those educational providers who survive, it is suggested here, will have to exhibit at least some of those characteristics of MOOCs (and other non-MOOC pockets of excellence) that have been shown to enhance value.

\section{Next Steps}

The VDBE model (and accompanying taxonomy), it might be argued, is overly simplistic...but it is a good starting point to raise the value question about higher education in America. Researchers are encouraged to offer alternative models, to consider revisions, or develop other useful taxonomies. The current authors have begun to develop (for future publication in VBDE Part 2) a research database of MOOC educational tools, processes, and methodologies that appear to be impactful. Educational researchers need to revisit basic, human performance research and perhaps re-examine what is already known about human cognition, theories of learning, and human motivation, for example, as some of that data might help us rethink how education can/should be delivered in a changing world. Future research, it goes without saying, should gather and analyze empirical data coming from past/current/future MOOC classes in a variety of settings. Finally, educational researchers should also develop a broader perspective and look for other (non-MOOC) educational developments, technologies, and learning modalities that could drive the value equation higher.

\section{AUTHOR INFORMATION}

David M. Gilfoil, Ph.D. is Associate Professor of Business and Director of the DeSales University MBA Program in Center Valley, Pennsylvania, USA. Prior to academia, Dr. Gilfoil spent 27 years in mid to upper level executive positions in global management, marketing and sales in the high tech industry. He holds a B.A. degree in Psychology from the University of Massachusetts, an M.A. in Cognitive/Experimental Psychology from the College of William and Mary, and a Ph.D. in Management Science from Stevens Institute of Technology. His research interests include global competency, business ethics, marketing and sales tools, social media in selling, and quality issues in healthcare and education. Email: david.gilfoil@desales.edu

Jeffrey W. Focht, Ed.D. is Assistant Professor of Business and Edward A. McCabe Chair of Business and Society at DeSales University, Pennsylvania, USA. He teaches courses in management and marketing and has 25 years of experience in corporate, small business, and higher education environments. He was vice president of academic affairs and dean prior to DeSales. Jeff holds an Ed.D. in higher education management from the University of Pennsylvania; an M.A. in liberal studies from Villanova University and; a B.S. in marketing from Central Connecticut State University. His research interests encompass higher education trends, business ethics, leadership development, and organizational practices influencing positive change. Email: jeffrey.focht@desales.edu

\section{REFERENCES}

Allen, I., \& Seaman. (2015). Grade level: tracking online education in the United States. Retrieved from http://www.onlinelearningsurvey.com/reports/gradelevel.pdf

Altbach, P. G. (2014). MOOCs as Neocolonialism: Who Controls Knowledge? International Higher Education, (75), 5-7.

Anderson, T. (2011). Towards a theory of online learning. In Anderson, T. (Ed.), The theory and practice of online learning. (45-74). AU Press: Athabasca University, Canada.

Anderson, J. C., Narus, J. A., \& Van Rossum, W. (2006). Customer value propositions in business markets. Harvard business review, 84(3), 90.

Asfar, V. (2013, November 17). Our educational leaders must get aggressive with technology. Retrieved from http://www.huffingtonpost.com/vala-afshar/our-educational-leaders-m_b_4292484.html.

Banta, T. W., Jones, E. A., \& Black, K. E. (2010). Designing effective assessment: Principles and profiles of good practice. John Wiley \& Sons.

Bisognano, M., \& Kenney, C. (2012). Pursuing the triple aim: seven innovators show the way to better care, better health, and lower costs. John Wiley \& Sons.

Bolton, R. N., \& Lemon, K. N. (1999). A dynamic model of customers' usage of services: Usage as an antecedent and consequence of satisfaction. Journal of marketing research, 171-186. 
Borwick, J. (2013). The value of higher education (for students). HEIT Management. Retrieved from http://www.heitmanagement.com/blog/2013/05/the-value-of-higher-education-for-students/

Carlson, S. (2013, April 22). How to assess the real payoff of a college degree. The Chronicle of Higher Education. Retrieved from http:/chronicle.com/article/Is-ROI-the-Right-Way-to-Judge/138665/

Cramer, M., Fisseni, B., Koepke, P., Kühlwein, D., Schröder, B., \& Veldman, J. (2010). The naproche project controlled natural language proof checking of mathematical texts. In Controlled Natural Language (pp. 170-186). Springer Berlin Heidelberg.

Cusumano, M. (2013). Are the costs of 'free' too high in online education? Considering the economic implications as educational institutions expand online learning initiatives. Communications of the ACM, 56(4), 26-29.

Cusumano, M. (2014). MOOCs revisited, with some policy suggestions. Communications of the ACM, 57(4), 2426.

Dellarocas, C., \& Van Alstyne, M. (2013). Money models for MOOCs. Considering new business models for massive open online courses. Communications of the ACM, 56(8), 24-26.

Dictionary, O. E. (2002). Concise Oxford English Dictionary.

Fain, Paul, (2011, November 11). More selective for-profits. Inside Higher Ed. Retrieved from https://www.insidehighered.com/news/2011/11/11/enrollments-tumble-profit-colleges

Finkel, T.A., \& Masters, E. (2014). Do MOOCs pose a threat to higher education? Research in Higher Education Journal, 2, 1-10.

Fisher, G. (2014) MOOCs: Beyond hype and underestimation: identifying research challenges for the future of MOOCs. Distance Education, 35(2), 149-158.

Flint, D. J., Woodruff, R. B., \& Gardial, S. F. (1997). Customer value change in industrial marketing relationships: a call for new strategies and research. Industrial marketing management, 26(2), 163-175.

Gale, B., \& Wood, R. C. (1994). Managing customer value: Creating quality and service that customers can see. Simon and Schuster.

Gikandi, J.W., Morrow, D., \& Davis, N.E. (2011). Online formative assessment in higher education: A review of the literature. Computers \& Education, 57, 2333-2351.

Gottlieb, L. 2013. Strengths-based nursing care: health and healing for person and family. New York: Springer Publishing

Gulwani, S., Radiček, I., \& Zuleger, F. (2014). Feedback generation for performance problems in introductory programming assignments. In Proceedings of the 22nd ACM SIGSOFT International Symposium on Foundations of Software Engineering (pp. 41-51). ACM.

Higgins, K. T. (1998). The value of customer value analysis. Marketing Research, 10(4), 38.

Hospital Consumer Assessment of Health Care Providers and Systems (HCAHPS) survey. Retrieved from http://www.hcahpsonline.org/home.aspx.

IHI triple aim intiative. (2014). Institute for Healthcare Initiatives Improvement Stories. Retrieved from http://www.ihi.org/resources/Pages/ImprovementStories/default.aspx

IHI triple aim initiative. (2009). Institute for Healthcare Improvement. Retrieved from http://www.ihi.org/Engage/Initiatives/TripleAim/pages/default.aspx

Institute of Medicine (2012). Best care at lower cost: The path to continuously learning healthcare in America. Report of the IOM, Sept 7, 2012.

James, J. T. (2013). A new, evidence-based estimate of patient harms associated with hospital care. Journal of Patient Safety, 9(3), 122-128.

Jortberg, B. T., \& Fleming, M. O. (2014). Registered dietitian nutritionists bring value to emerging health care delivery models. Journal of the Academy of Nutrition and Dietetics, 114(12), 2017-2022.

Kamenetz, A. (2012, February 7). Most innovative companies 2012. Fast Company. Retrieved from http:/www.fastcompany.com/3017340/most-innovative-companies-2012/12southern-new-hampshireuniversity

Kaplan, R. S., \& Porter, M. E. (2011). How to solve the cost crisis in health care. Harvard Business Review, 89(9), 46-52.

Kay, R. H. (2012). Exploring the use of video podcasts in education: A comprehensive review of the literature. Computers in Human Behavior, 28(3), 820-831.

Khalil, H. \& Ebner, M. (2013). How satisfied are you with your MOOC? A Research Study on Interaction in Huge Online Courses. In Jan Herrington et al. (Eds.), Proceedings of World Conference on Educational Multimedia, 
Hypermedia and Telecommunications, 830-39. Chesapeake, VA: AACE. Retrieved from http://www.editlib.org/p/112057.

Kohn, L. T., Corrigan, J. M., \& Donaldson, M. S. (Eds.). (2000). To Err Is Human: Building a Safer Health System (Vol. 627). National Academies Press.

Kolowich, S. (2012, October 16). Texas MOOCs for credit? Inside Higher Ed. Retrieved from https:/www.insidehighered.com/news/2012/10/16/u-texas-aims-use-moocs-reduce-costs-increasecompletion

Kop, R. (2011). The challenges to connectivist learning on open online networks: Learning experiences during a massive open online course. The International Review of Research in Open and Distance Learning, 12(3), 19-38.

Kordupleski, R. (2003). Mastering customer value management: The art and science of creating competitive advantage. Customer Value Management I.

Kotler, P. (2012). Kotler on marketing. Simon and Schuster.

Krupnick, M. (2013, November 11). Will beaten down for-profit colleges bounce back? CNN Money. Retrieved from http://money.cnn.com/2013/11/11/pf/college/for-profit-colleges/

Laitamäki, J., \& Kordupleski, R. (1997). Building and deploying profitable growth strategies based on the waterfall of customer value added. European Management Journal, 15(2), 158-166.

Lan, A. S., Vats, D., Waters, A. E., \& Baraniuk, R. G. (2015). Mathematical Language Processing: Automatic Grading and Feedback for Open Response Mathematical Questions. arXiv preprint arXiv: 1501.04346.

Lapp, D., Wolsey, T.D., \& Ganz, P. (2013, Winter). Rigorous real-world teaching and learning: Guidelines for providing online feedback that motivates students to learn. International Reading Association.

Lanning, M. J., \& Michaels, E. G. (1988). A business is a value delivery system. McKinsey staff paper, 41(July).

Lanning, M., \& Phillips, L. (1991). Building market-focused organizations. white paper, Gemini Consulting.

Lawton, W., \& Katsomitros, A. (2012). MOOCs and disruptive innovation: The challenge to HE business models. The Observatory on Borderless Higher Education. Retrieved from http://www.voced.edu.au/content/ngv55175?utm_source=twitterfeed\&utm_medium=twitter

Lee, G. (2014, October 3). How one university became exhibit A of marketing success. The Chronicle of Higher Education, p.15.

Lindgreen, A. and Wyndstra, F. (2005), "Value in business markets: what do we know? Where are we going?", Industrial Marketing Management, Vol. 34, pp. 732-48.

Lucas, H. (2014). Disrupting and Transforming the University. Higher education institutions must modify their business models in response to technology-driven influences. Communications of the ACM, 57(10), 32-35.

Magana, S., \& Marzano, R.J. (2014). Enhancing the art and science of teaching with technology. Bloomington, ID: Marzano Research Laboratory.

Marcinek, A. (2014). Technology and teaching: finding a balance. Retrieved from http://www.edutopia.org/blog/technology-and-teaching-finding-balance-andrew-marcinek

Masters, K. (2011). A brief guide to understanding MOOCs. The Internet Journal of Medical Education, 1(2).

McDougall, G. H., \& Levesque, T. (2000). Customer satisfaction with services: putting perceived value into the equation. Journal of services marketing, 14(5), 392-410.

Middaugh, M.F. (2010). Planning and assessment in higher education: Demonstrating institutional effectiveness. San Francisco, CA: Jossey-Bass.

North, S.M., Richardson, R., \& North, M.M. (2014). To adapt to MOOCs, or not? That is no longer the question. Universal Journal of Educational Research, 2(1), 69-72.

Ojalvao, H.E. (2012, February 2). Why go to college at all? The New York Times. Retrieved from http://thechoice.blogs.nytimes.com/2012/02/02/why-go-to-college-at-all/

Olaru D., Purchase S., \& Peterson, N. (2007). From customer value to repurchase intentions and recommendations. Journal of Business and Industrial Marketing, 23, 554-565.

Oliver, R. L., \& DeSarbo, W. S. (1988). Response determinants in satisfaction judgments. Journal of consumer research, 495-507.

Ory, M. G., Ahn, S., Jiang, L., Smith, M. L., Ritter, P. L., Whitelaw, N., \& Lorig, K. (2013). Successes of a national study of the Chronic Disease Self-Management Program: meeting the triple aim of health care reform. Medical care, 51(11), 992-998.

Pappano, L. (2012, November 2). The year of the MOOC. The New York Times, 2(12), 2012.

Porter, E. (2014, October 7). Why aid for college is missing the mark. The New York Times. Retrieved from 
http:/www.nytimes.com/2014/10/08/business/economy/why-federal-aid-for-higher-education-is-missingthe-mark.html

Porter, M. E. (2010). What is value in health care? New England Journal of Medicine, 363(26), 2477-2481.

Porter, M. E. (2009). A strategy for health care reform - toward a value-based system. New England Journal of Medicine, 361(2), 109-112.

Porter, M. E. (1991). Competitive advantage. Planning, 24(4).

Porter, M. E. \& Teisburg, E. O. (2006). Redefining healthcare: Creating value-based competition on results. Boston, MA: Harvard Business School Press.

Rampel, C. (2011, May 18). Many with new college degree find job market humbling. The New York Times. Retrieved from http://www.nytimes.com/2011/05/19/business/economy/19grads.html?scp=1\&sq=jobs\%20require\%20colle ge $\% 20$ degree $\% 20$ young $\% 20$ college $\% 20$ graduates\&st $=$ cse

Ravald, A., \& Grönroos, C. (1996). The value concept and relationship marketing. European journal of marketing, 30(2), 19-30.

Rivers, K., and Koedinger, K. (2014). Automating hint generation with solution space path construction. In Proceedings of the 12th International Conference on Intelligent Tutoring Systems (June), 329-339.

Sampson, D. \& Karagiannidis, C. (2002). Personalised learning: educational, technological, and standardisation perspective. Interactive Educational Multimedia, (2), April, 24-39.

Sandeen, C. (2013). Integrating MOOCs into higher education: The emerging "MOOC 3.0" era. Change, 45(6), 3439.

Siemens, G. (2010). Managing and Learning in MOOCs (massive open online courses). Retrieved from http://auspace.athabascau.ca/bitstream/2149/2838/4/George_Siemens.pdf

Skiba, D. J. (2012). Disruption in higher education: Massively open online courses (MOOCs). Nursing education perspectives, 33(6), 416-417.

Southavilay, V., Yacef, K., Reimann, P., and Calvo, R. (2013) Analysis of collaborative writing processes using revision maps and probabilistic topic models. In Proceedings of the 3rd International Conference on Learning Analytics and Knowledge pp.38-47.

U.S. Department of Education. (2014). Competency-based learning or personalized learning.

Retrieved from http://www.ed.gov/oii-news/competency-based-learning-or-personalized-learning

Vardi, M. Y. (2012). Will MOOCs destroy academia? Communications of the ACM, 55(11), 5.

Vihavainen, A., Luukkainen, M., \& Kurhila, J. (2012, October). Multi-faceted support for MOOC in programming. In Proceedings of the 13th annual conference on Information technology education (pp. 171-176). ACM.

Williams, J.J. (2013). Applying cognitive science to online learning. Paper presented at the Data Driven Education Workshop at the Conference on Neural Information Processing Systems.

Retrieved from http://lytics.stanford.edu/datadriveneducation/papers/williams.pdf

Williams, J.J \& Williams, B. (2014). Using interventions to improve student learning. Retrieved from http://lytics.stanford.edu/datadriveneducation/papers/williamswilliams.pdf

Zemsky, R. (2013). Checklist for change: Making higher education a sustainable enterprise. New Brunswick, NJ: Rutgers University Press.

Zemsky, R., Wegner, G.R., \& Massey, W.F. (2006). Remaking the American university: Market-smart and missioncentered. New Brunswick, NJ: Rutgers University Press. 


\section{NOTES}

